ISBN 978-93-86878-06-9

8th International Conference on Literature, Languages, Humanities and Interdisciplinary Studies

(LLHIS-17)

Kuala Lumpur (Malaysia) Dec. 14-15, 2017

\title{
The Impact of Mimicry and Othering in Kam Raslan's Confession of an Old Boy: The Dato' Hamid Adventures
}

\author{
Afifah Mohamad Radzi ${ }^{1}$ and Mohd Hasrul Kamarulzaman ${ }^{1}$ \\ ${ }^{1}$ Pusat PERMATApintar ${ }^{\circledR}$ Negara, Universiti Kebangsaan Malaysia, Malaysia
}

\begin{abstract}
Mimicry is the action or skill of imitating someone or something in order to either entertain or ridicule while othering is the view or treat (a person or group of people) as intrinsically different from and alien to oneself. These concepts are common and persist in any civilised social community because they play significant roles in socialisation and thus have crucial impact on the individuals involved. Examples of these concepts are portrayed in Kam Raslan's 'Confessions of an Old Boy: The Dato' Hamid Adventures'. This paper examines mimicry and othering displayed by an Anglophile character in Kam Raslan's, an Anglophile in the form of one Dato' Hamid, the perfect subject of British colonisation. His character is analysed through the ways he others people whose journey differs from his, and through the ways he mimics the British or the white men whom he regards very highly. The analysis presents the prevalent forms of mimicry and othering constructed by Kam Raslan. The overall finding elucidates the successful transfer of British colonial ideology to individuals as the impact of mimicry and othering.
\end{abstract}

Keywords: mimicry, othering, anglophile, colonised mind, ambivalence

\section{Introduction}

Confessions of an Old Boy: The Dato' Hamid Adventures written by Kam Raslan narrates a story about Dato' Hamid, a government civil servant whose mind, attitude and behaviour are very much shaped and influenced by British ideology and culture. Having gone to Malaysia's premier school, Malay College Kuala Kangsar (MCKK) which was built during British colonisation and which has brought in teachers from Britain to educate the boys of Malay aristocracy and royalty, Dato' Hamid has developed a mind-set and lifestyle similar to the British or white men. Since small, he has been absorbing colonial ideas and thinking that the best and the most respected way to live life is by 'being English'. Due to this kind of mind-set, like it or not, Dato' Hamid has embraced Mimicry, one of the key concepts in Homi Bhabha's Ambivalence theory as well as Othering, a key concept under Edward Said's Orientalism.

The writer of this book is quite well-known especially among theatre activists and columnists. Apart from being a writer, Kam Raslan is also a director working in theatres, films and televisions. He currently contributes to The Edge weekly and Off the Edge magazine as a columnist. Not much work or research being done on Kam Raslan and/or his Confessions of an Old Boy novel and studies or publications on both of them are mostly discussed MCKK and Dato' Hamid character, leaving some gaps for other potential researches. To occupy this gap, this paper employs the concepts of mimicry and othering to prove the existence of colonial ideology in Dato' Hamid character.

As mentioned earlier, Othering is a key concept under Orientalism, first came to be known in 1977 when a Middle Eastern scholar named Edward Said wrote and published a book titled 'Orientalism'. His book has opened the eyes of so many people, and not only that, people's mind becomes full with issues, stories and words on Orientalism. Said coined this term to show the wrong and negative perceptions made by most Western people 
towards Middle Eastern countries and their people. The Orients can also refer to Asian people as they have also been the object of ridicule to the West.

Meanwhile, Ambivalence is a term introduced by Homi Bhabha and is somewhat different from Orientalism and it is not at all similar to the concept of binary oppositions championed by Edward Said, yet it shows the complexities of the relationship between the coloniser and the colonised. Through this theory, Homi Bhabha believes that not only the colonised people are affected by the white, but the colonisers are also receiving some impacts from the native people. Thus, ambivalence delves into the problems that emerge from the relationships between the coloniser and the colonised.

One of the key concepts listed under Ambivalence is Mimicry, a term used to describe the native people or those who have been colonised who are trying to mimic their colonisers or the white men. This form of mimicry can happen in terms of speech, clothing, mind-sets, lifestyle and so on. Throughout the novel, Dato' Hamid has evidently shown mimicry when he lives life like the English, has faith in them as well as speaks, dresses and thinks like them.

The purpose of this paper is to analyse the manifestations of Othering and Mimicry in Kam Raslan's Confessions of an Old Boy and to show the successful transfer of British culture and ideology to native people in Malaysia, particularly those living and studying during British colonisation. Ironically, while championing English lifestyle, Dato' Hamid has at the same time shown himself as a failed colonial imitation as he can only mimic the white men, but can never be one of them.

\section{Literature Review}

As mentioned earlier, not much work has been done on both the writer and the book, yet there is a number of studies that deal with ambivalence, mimicry as well as othering in some other novels. Ahmad Thamrini Fadzlin Syed Mohamed, a lecturer and researcher from National Defence University Malaysia through his paper Programming the Latent: A Post Colonial View on Kam Raslan's Confessions of an Old Boy ${ }^{[1]}$ has discussed the impacts of English Public School system implemented in MCKK from post-colonial views. For this research, he has applied three key terms found in Edward Said's Orientalism; Knowledge and Power, Eurocentrism and Othering. The results of his study reveal that this novel has succeeded in proving the sustenance of colonial ideology in Malaysia even after independence.

Another study by the same writer with Noraini Md. Yusof and Ruzy Suliza Hashim entitled Making of a Native Orientalist: Latent Orientalism in Confessions of an Old Boy: The Dato' Hamid Adventures ${ }^{[2]}$ examines the sustaining effects of colonialism through education particularly in MCKK, one of the premier's schools in Malaysia. Dato' Hamid character clearly shows a total success of the implementation of British culture and ideology after they have left this country.

Finally, the third article Identity in Arundhati Roy's The God of Small Things and Kiran Desai's The Inherintance of Loss: Ambivalence and Mimicry ${ }^{[3]}$ by Ivana Maric has revealed the application of Ambivalence and Mimicry theory to discuss the issue of identity, particularly through the characters Pappachi in TGOST and the judge in TIOL. As a subject of colonisation, these two characters experience mixed, hybrid and ambivalent identity as well as mimicry.

The first two studies allow this paper to explore more on the concept of mimicry, presenting and discussing it in detail by focusing only on one character. In addition, they also provide an in-depth understanding of othering from within; when a native others another native, shedding light on other characters, such as Hamzah and Megat. The findings of this paper showed the successful manifestations of othering and mimicry through the character of Dato' Hamid and how he has effectively absorbed British colonial ideology. 


\section{Theoretical Framework}

In analysing the character of Dato' Hamid, this paper applies the concepts of mimicry proposed by Homi Bhabha and othering by Edward Said. According to Said, Orientalism refers to "the corporate institution for dealing with the Orient - dealing with it by making statements about it, authorizing views of it, describing it, by teaching it, settling it, ruling over it: in short, Orientalism as a Western style for dominating, restructuring, and having authority over the Orient" ${ }^{[4]}$ (Said 1979). It looks at the representations of the Orient or the Other being marginalised by the white men or the colonisers as the latter are those in power and they feel they have the right to view other people as inferior and uncivilised.

When one talks about Orientalism, the negative portrayals of Middle Easterners by the self-claimed superior and civilised Westerners will always come to mind. But, are Europeans and/or white people the only one who view the people of Middle Eastern countries differently? To challenge the common thoughts and at the same time answering the above question, this paper will discuss and analyse the key concept of Orientalism i.e. Othering.

Othering refers to the act of downgrading so-called inferior human beings by emphasising their strangeness. This term usually comes to play when someone of a high rank or someone who believes that he/she is more superior than others starts to see them as inferior, mostly because they are not similar to him/her. Therefore, the native themselves can also view others who come from the same populations negatively and differently, inserting the feeling of superiority, power and control over the people being 'othered', in a way confirming that the concept of othering can no more be applied only on the white people.

Meanwhile, mimicry is a part of Ambivalence theory introduced by Homi Bhabha. In his article Of Mimicry and Man: The Ambivalence of Colonial Discourse, Bhabha defines mimicry as something that "emerges as the representation of a difference that is itself a process of disavowal" ${ }^{[5]}$ (Bhabha: 265). This concept refers to a colonial subject who will be recognisably similar to the coloniser, yet is still different. A native person can imitate any white man, but there will be events where the resemblance will be denied, and usually the truth is shown by the colonised themselves.

In the same article, Bhabha views mimicry "as one of the most elusive and effective strategies of colonial power and knowledge" ${ }^{5]}$ (Bhabha: 265). To connect this definition to Kam Raslan's novel, it is crucial to point out that Dato' Hamid tries his best to look like an English man. He has gone to MCKK where he was educated and trained to embrace English lifestyle, to think like his colonisers, to speak and dress like them. His character evidently shows the effectiveness of British colonial power and knowledge strategy in brainwashing people in their colonies.

\section{Analysis and Discussion}

One of the main intentions of this paper is to look at the ways Dato' Hamid perceives the Other as narrated in Kam Raslan's Confessions of an Old Boy. If we are to take Edward Said's words in defining who is the Other, the answer is the Orients; the non-European people who were once colonised by the white, those of lower status, uncivilised and uneducated. However, in order to analyse the Other through Dato' Hamid's eyes, we cannot simply take Said's definition because it is Hamzah who is seen as the Other, yet is educated, civilised and rich.

"I want you to go to the house of Desmond Ong. He's having a weekend party there and I'm supposed to go but I absolutely cannot. I want you and your wife to represent me. Can you do that?"

"Yes, Tun."

"And I want you to give a lift to Hamzah Othman. You know him, don't you?"

"Yes, Tun." The line went dead and my weekend was ruined. Of course I knew Hamzah, but I didn't know him at all well. He's not from MCKK but from St John's. Surprisingly, for a St John's Boy, he was considered to be quite intelligent and only slightly effeminate. ${ }^{[6]}$ (Kam Raslan 2007: 140-141) 
There are many things going on in the above excerpt, especially when an MCKK boy is talking about a St John's boy who he claims to be less than him in many ways. Dato' Hamid obviously denigrates and looks down on Hamzah just because of the different schools they go to, proving the existence of Othering when Hamzah is othered due to attending a non-premier school. Having studied in MCKK, Dato' Hamid has a certain preference of people and without even meeting Hamzah, he happily calls him 'effeminate', giving him an unmanly character. This shows how highly Dato' Hamid places himself among other Malays, because he is the subject of British empire, who has direct contacts with British officials and has visited all parts of the world while working with and for the British. Even though Dato' Hamid seems to acknowledge Hamzah's intelligence, the word 'quite' placed before the adjective 'intelligent' suggests that Dato' Hamid perceives his intelligence to be higher than Hamzah's.

"So we're finally going to meet Hamzah Othman."

I didn't like the girlish way she said that and told her so.

"There's no need to get jealous, Hamid. It's just that I've heard so much about him. They say he's extremely intelligent and that he's a bit of a dreamer. And they say he's very charming. He must have a sensitive soul..." her words trailed off dreamily. I really didn't like the sound of that. ${ }^{[6]}$ (Kam Raslan 2007: 141-142)

The Wife seems happy and excited to meet Hamzah and Dato' Hamid clearly hates to see or listen to her excitement. He believes that Hamzah is always lower than him, for being a St John's boy, not having any permanent job and living with his mother. In the previous excerpt, Dato' Hamid uses the word 'quite' to describe Hamzah's intelligence, on the other hand, his European wife happily announces Hamzah to be 'extremely' intelligent. Since Dato' Hamid's mind has been colonised by British ideology which has led him to always believe that he is better than anybody else, there is never a way for someone like Hamzah who does not attend MCKK to ever beat him. Thus, the above excerpt evidently verifies Othering towards Hamzah.

“We really must get going, Hamzah. It's a long drive, " I politely pressed.

"But you must have something to eat while I shower. Is the music bothering you?"

"I don't care much for popular music."

"My guess is that your tastes are more operatic."

“Well, yes," I said patronisingly as I could. ${ }^{[6]}$ (Kam Raslan 2007: 143)

The above conversation proves how Dato' Hamid positions himself highly through music, indicating his Englishness and wealthy way of life. Opera is always associated with rich people and he is indeed a person who enjoys operatic music. The word 'patronisingly' clearly says how he looks down on Hamzah for playing popular music while he enjoys opera. Dato’ Hamid is obviously othering Hamzah for his music taste that is different from his.

"Hamzah returned dressed in an outfit strangely locked into the 1970s-a polka dot shirt with some big collar and tight-fitting trousers with big flares. I'm no follower of fashion (classic English style is timeless and a safari jacket is good for any occasion), but even I knew that his sense of style was out of date." [6] (Kam Raslan 2007: 144)

Even though in the above excerpt Dato' Hamid claims that he is not a follower of fashion, he does realise Hamzah's outdated fashion sense. Importantly, he mentions 'classic English style is timeless' which depicts how he highly regards English appearance, something that he always pays extra attention to. This in a way confirms Dato' Hamid's view of Hamzah as someone different and strange because the way he dresses up does not reflect the prim and proper English people. Hamzah is again othered, and this time because of his clothing.

The above excerpt can also be analysed from the concept of mimicry, particularly by looking at Dato' Hamid's fashion sense. Since he is so obsessed with living like an English man, his type of clothing always displays the Englishness that he tries to imitate, dressing up neatly, properly and primly. By saying "classic 
English style is timeless", he has proven how much he prefers English fashion style because that is how he has been trained since school, that being English is always good and respected.

"The Grandson is a chip off the old block. He could be one of my generation. We have the ability to travel anywhere and mix with anybody from Lagos to London, from penthouse to pavement, because we understand what it is to govern and be governed. We worked with the British and for the British. We had been taught by them and then were abandoned by them when the Japanese came. We have had every twentieth-century experience one can possibly imagine. We were colonised but we were also the leaders. So we understand people. And we travel. There is not a corner of this planet that hasn't been visited by one of the boys, some of whom never came back but all of will be Malay till their dying breath. I should know, I was so very nearly one of them. But that was what it was, back then, to be Malay. We carried it in our hearts: food, family, modesty, adventure and faith. But, as I say, we carried it in our hearts, we didn't need to grow it on our chins. The Ayatollah's generation is a Malay anomaly. I don't know where they came from and I don't know where they're taking us." ${ }^{[6]}$ (Kam Raslan 2007: 24-25)

The above quote clearly shows how someone of Dato' Hamid's generation should act and live, and this is also how he lives his life as a subject of the British empire. His own son is not a Malay he expects him to be, yet his grandson more or less portrays the characteristics which Dato' Hamid deems to be right and accepted. Having been taught in MCKK with British syllabus and education system, he has learnt quite a number of ways to be similar to the British or to mimic them which then prove that he has some ideological thoughts about being an English educated person. Dato' Hamid does not think it is necessary to grow beards like his son if someone needs to show his 'Malayness', simply because he looks at himself as a person working with and for the British, thus he must appear prim and proper, just like other British men.

"But I see you had the foresight to bring your tuxedo to London."

"It's called 'black tie' and you know that I never go anywhere without it." (Kam Raslan 2007: 73).

"Have some sirup, 'Mid."

"I hate sirup."

"Air Bandung?"

"It stands to reason that if I hate sirup, then I'll hate Ayer Bandong."

"You're an Englishman, 'Mid," Ariff laughed. ${ }^{[6]}$ (Kam Raslan 2007: 80)

In order to make himself presentable like most English men, Dato' Hamid always appears smart in tuxedo or black tie, and again, this shows the occurrence of mimicry. Whether he realises it or not, everyone around him notices his being-English obsession and the way Ariff points out about the tuxedo is in a way mocking and ridiculing Dato' Hamid for his endless mimicking of the people who once have colonised him. Not only that, even his choice of drinks proves that he looks more or less like an English man.

\section{Conclusion}

To sum up this paper, it is vital to confirm that the main character in Confessions of an Old Boy: The Dato' Hamid Adventures by Kam Raslan has successfully conformed to the concepts of othering and mimicry. This conformity is caused by quite a number of factors; being an MCKK boy, being taught to think like the British people as well as being decided to join the government as a civil servant to work for the British and with the British. In addition, the textual evidence pointed out through this paper strengthens the fact that British colonial ideology is still relevant in Malaysia even after Independence. 


\section{References}

[1] A. T. F. S. Mohamed, "Programming the latent: a post colonial view on Kam Raslan's Confessions of an Old Boy," International Journal of Interdisciplinary Social Sciences, vol. 5, pp. 75-90, March 2010.

[2] A. T. F. S. Mohamed, N. M. Yusof, and R. S. Hashim, "Making of a native orientalist: latent orientalism in Confessions of an Old Boy: The Dato' Hamid Adventures," The Southeast Asian Journal of English Language Studies, vol. 16, pp. 140-198, June 2010.

[3] I. Marić, "Postcolonial readings of identity in Arundhati Roy's The God of Small Things and Kiran Desai's The Inheritance of Loss: ambivalence and mimicry," in Proc. English Language and Anglophone Literatures Today, 2011, pp. 508-517.

[4] S. Edward, Orientalism. London: Penguin, 1977.

[5] H. Bhabha, "Of Mimicry and Man: The Ambivalence of Colonial Discourse," in Postcolonialisms: An Anthology of Cultural Theory, G. Desai and S. Nair, 2005, ch. 19, pp. 265-273.

[6] K. Raslan, Confessions of an Old Boy: The Dato' Hamid Adventures. Shah Alam: Marshall Cavendish, 2007. 